\title{
THE CONCEPT OF CORRUPTION IN CAMPAIGN FINANCE LAW
}

\author{
Thomas F. Burke*
}

In Buckley vs. Valeo, 1 the Supreme Court put the concept of corruption at the center of campaign finance law. The Court held that only society's interest in preventing "corruption and the appearance of corruption" outweighed the limits on free expression created by restrictions on campaign contributions and expenditures. Other goals, such as equalizing the influence of citizens over elections, limiting the influence of money in electoral politics, or creating more competitive elections, were rejected as insufficiently compelling to justify regulating political speech. 2 The Court's focus on corruption has been reiterated in a series of cases following Buckley, which have decided whether various provisions of the Federal Election Campaign Act, or local laws, violate the First Amendment. ${ }^{3}$ Barring a major shift in this area of law, corruption is the criterion by which the constitutionality of further reforms in campaign finance regulation will be measured.

The Court's emphasis on "corruption and the appearance of corruption" has stimulated criticism on several fronts. From the left, the Court is criticized for not giving credence to other interests served by campaign finance regulation. 4 From the right comes the criticism that the Court has been inconsistent in its

* Copyright () 1997 by Thomas F. Burke, Assistant Professor of Political Science, Wellesley College. Ph.D. 1996, Political Science, University of California-Berkeley; B.A. 1988, Mass Communications, University of Minnesota. I wish to thank Jonathan Bemstein, Bruce Cain, Paul Edwards, Daniel Lowenstein, Hanna Pitkin, Nelson Polsby, and Dennis Thompson for their helpful comments on earlier drafts of this paper.

1. 424 U.S. 1 (1975).

2. Id. at 25-27.

3. First National Bank of Boston v. Bellotti, 435 U.S. 765 (1978); Citizens Against Rent Control v. Berkeley, 454 U.S. 290 (1981); California Medical Ass'n v. FEC, 453 U.S. 182 (1981); FEC v. National Right to Work Comm., 459 U.S. 197 (1982); FEC v. National Conservative Political Action Comm., 470 U.S. 480 (1985); FEC v. Massachusetts Citizens For Life, Inc., 479 U.S. 238 (1986); Austin v. Michigan Chamber of Commerce, 494 U.S. 652 (1990); and Colorado Republican Federal Campaign Comm. v. FEC, 116 S. Ct. 2309 (1996).

4. J. Skelly Wright, Money and the Pollution of Politics: Is the First Amendment an Obstacle to Political Equality?, 82 Colum. L. Rev. 609 (1982). 
application of the corruption standard.5 Others find the problem in the term "corruption" itself. Frank Sorauf argues that while the phrase "has a ring that most Americans will like ... its apparent clarity is deceptive, and its origin is at best clouded."6 Yet whatever its flaws, politicians, activists, judges and even picky academics continually employ the concept of corruption in their claims about the campaign finance system. I hope in this article to give some sense of both the possibilities and the limits of understanding campaign finance as an issue of corruption.

The first part of the article briefly considers the concept of corruption and the ways in which academic commentators have explored it. The second part analyzes how "corruption" has been employed in a series of Supreme Court cases beginning with Buckley. Finally, the third part defends what I call the "monetary influence" standard of corruption as the most appropriate one to use in controversies over campaign finance. This defense turns out to be a rather complex enterprise; it requires a turn back to the foundations of representative democracy. Any adequate standard of corruption, I argue, must be grounded in a convincing theory of representation.

\section{THE CONCEPT OF CORRUPTION}

Even the dictionary definitions of corruption suggest that it is a tricky term. The Oxford English Dictionary gives nine basic definitions of corruption, but there is an element common to all: a notion that something pure, or natural, or ordered has decayed or become degraded. Corruption was used in medieval times to denote physical processes such as infection or decomposition.7 When corruption is proclaimed in political life it presumes some ideal state. Corruption is thus a loaded term: you cannot call something corrupt without an implicit reference to some ideal. In order to employ the concept of corruption in the context of a political controversy, such as that over campaign finance, one must have some underlying notion of the pure, original or natural state of the body politic.

5. See Antonin Scalia's dissent in Austin, 494 U.S. at 679.

6. Frank J. Sorauf, Caught in a Political Thicket: The Supreme Court and Campaign Finance, 3 Const. Comm. 97, 103 (1986). See also two wide-ranging critiques of the Court's corruption standard: Jonathan Bernstein, Goo Goo Terror, 95 Inst. of Govemmental Studies Working Paper 22, Institute of Governmental Studies, University of California-Berkeley (1995); and Ron Schmidt, Jr., Defining Corruption: Plunkitt to Buckley and Beyond, 95 Institute of Governmental Studies Working Paper 21, Institute of Govemmental Studies, University of California-Berkeley (1995).

7. J.A. Simpson and E.S.C. Weiner, eds., 3 The Oxford English Dictionary 972-74 (Clarendon Press, 2d ed. 1989). 
Not surprisingly, then, academics have had difficulty arriving at satisfactory criteria for deciding what is corrupt. James Scott divides attempts into three approaches: legal norms, public opinion, and the public interest. 8 A legal norms approach focuses on the laws and formal rules of a given society in determining what is corrupt and what is not. 9 While such an approach may be useful in comparative research, it seems unlikely that it can help us in a discussion of a legal controversy. 10 After all, we can't very well refer to the rules of our society when the issue is what those rules should be.

The public opinion approach is similarly problematic. 11 It may seem sensible to define what is corrupt by finding out what most people in a given society consider corrupt, but on most of the interesting questions public opinion is likely to be ambiguous. As Scott points out, there is no clear, non-arbitrary way to decide what level of social consensus is necessary before we declare a given act corrupt.12 Should a mere majority be sufficient, or should unanimity be required? Should the opinions of the more educated, those better informed, or those more interested in politics, be given more weight? Public opinion will always be an unsteady guide except in the easy cases.

Finally there is the public interest approach, which involves defining some ideal against which corrupt conduct can be measured. This approach merely gauges what is corrupt in terms of an even more contested concept, the "public interest." Political scientists, who have given the most thought to the concept of cor-

8. See James C. Scott, Comparative Political Corruption 3-5 (Prentice Hall, Inc., 1972). For a full discussion of the ways in which corruption has been defined in political science, see Amold J. Heidenheimer, ed., Political Corruption: Readings in Comparative Analysis 3-8 (Holt, Rinehart and Winston, Inc., 1970). This book contains a vast number of essays and articles by comparative and American political scientists on corruption. One attempt to consolidate the various definitions into one coherent scheme is John G. Peters' and Susan Welch's, Political Corruption in America: A Search for Definitions and a Theory, or If Political Corruption Is in the Mainstream of American Politics Why Is It Not in the Mainstream of American Politics Research?, 72 Am. Pol. Sci. Rev. 974 (1978).

9. This is the approach taken, for example, by Joseph Nye, who defines corruption as "behavior which deviates from the formal duties of a public role because of privateregarding (personal, close family, private clique) pecuniary or status gains; or violates rules against the exercise of certain types of private-regarding influence." J.S. Nye, Corruption and Political Development: $A$ Cost-Benefit Analysis in Heidenheimer, ed., Political Corruption 564, 566-67 (cited in note 8).

10. This is a point Dan Lowenstein makes in his article Political Bribery and the Intermediate Theory of Politics, 32 UCLA L. Rev. 784 (1985). Lowenstein discusses the problem of defining corruption at 798-804.

11. Heidenheimer takes a modified public opinion approach; he considers the opinions of both public officials and mass public opinion. See Heidenheimer, ed., Political Corruption at 3-28 (cited in note 8).

12. Scott, Comparative Political Corruption at 4 (cited in note 8). 
ruption, have had trouble even agreeing that there is some such thing as the public interest, much less defining what that interest involves. ${ }^{13}$ Thus all three approaches have serious problems.

Fortunately, for the purposes of this article I need not pretend that there is some unifying, global criterion of corruption. Rather, my task is to give some sense to the term as it is used in the discussion of campaign finance law. Yet even in this more limited realm it is hard to see where we are to draw our standards from.

\section{CORRUPTION AND THE CAMPAIGN FINANCE CASES}

Buckley and its progeny are complex, confusing cases. At times even passages in a single opinion seem to contradict each other. Thus it is no surprise that commentators have differed in their interpretation of the Court's treatment of corruption. Lillian BeVier, writing in 1985, concludes that under the Court's rulings the "only activity that may become the target of corruptionpreventing legislation is that of securing or attempting to secure 'political quid pro quos from current and potential officeholders."' 14 By this criterion, only pre-arranged deals-trades of votes for money-qualify legally as corrupt. Paul Edwards further develops the quid pro quo standard of corruption and claims that with Austin the Court made a "dramatic change" in its approach by veering away from this limited definition of corruption to a much broader one, influenced perhaps by Rawlsian liberalism. ${ }^{15}$ Frank Sorauf, by contrast, finds hints even in the earlier

13. Frank Sorauf reviewed this debate in The Public Interest Reconsidered, $19 \mathrm{~J}$. of Politics 616 (1957). Sorauf criticizes the term as "subjective and imprecise" and calls various definitions of it "illogical." Id. at 633. Sorauf argues that outcomes of public policymaking cannot be judged by a public interest standard. Nevertheless, Sorauf says there is a public interest in the process by which policies are created. Thus Sorauf identifies the public interest with the "process of group accommodation." Id. at 638 . This leaves some ground for pluralists like Sorauf to use a public interest concept in evaluating campaign finance procedures. Robert Dahl similarly finds the "common good" in "practices, arrangements, institutions, and processes that .. .promote the well-being of ourselves and others ...." Robert A. Dahl, Democracy and Its Critics 307 (Yale U. Press, 1989). Like Sorauf, Dahl's discussion of practices that promote the common good suggests that Dahl could employ a public interest concept in evaluating issues of campaign finance.

14. Lillian R. BeVier, Money and Politics: A Perspective on the First Amendment and Campaign Finance Reform, 73 Cal. L. Rev. 1045, 1082 (1985). BeVier is quoting from Buckley, 424 U.S. at 26.

15. Paul S. Edwards, Defining Political Corruption: The Supreme Court's Role, 10 BYU J. Pub. L. 1, 3 (1996). 
cases that the Court's concerns went beyond pure quid pro quos. 16

While quid pro quo is no doubt a major theme in the campaign finance cases, I think Sorauf is right to suggest that the Court went well beyond this standard even before Austin. In the series of cases beginning with Buckley and ending with Austin, three distinct standards of corruption that are advanced, though at several points the Court blurs them. I label them quid pro quo, monetary influence, and distortion.

The quid pro quo standard is simply that it is corrupt for an officeholder to take money in exchange for some action. The money may be a bribe for personal use or a campaign contribution. The deal is explicit, with both sides acknowledging that a trade is being made.

The monetary influence standard is broader. Here the root idea is that it is corrupt for officeholders to perform their public duties with monetary considerations in mind. The influence of money is corrupting under this standard even if no explicit deal is made.

The third standard of corruption is distortion. The ideal behind this standard is that the decisions of officeholders should closely reflect the views of the public. Campaign contributions are corrupting to the extent that they do not reflect the balance of public opinion and thus distort policymaking through their influence on elections.

The three standards of corruption-quid pro quo, monetary influence and distortion-have been jumbled together in the corpus of campaign finance law.

\section{Quid Pro Quo Versus Monetary Influence}

In Buckley, the Court struck down limitations on campaign expenditures, but upheld contribution limits. Contributions, the Court said, were less speech-like than expenditures and thus deserved lesser protection. 17 But contributions are also more regulatable because they, unlike expenditures, can be a source of corruption by influencing the conduct of representatives. While the Court at first emphasizes the danger of quid pro quo in dis-

16. "But while the quid pro quo is the nub of the matter, it is perhaps not the totality of it." Sorauf, 3 Const. Comm. at 103 (cited in note 6).

17. Buckley, 424 U.S. at 24-29. 
cussing the problem of corruption, 18 it also notes that the state's interest goes beyond mere bribery: "But laws making criminal the giving and taking of bribes deal with only the most blatant and specific attempts of those with money to influence governmental action." 19 This pattern is repeated in succeeding cases. The Court mentions the quid pro quo standard, but also suggests that corruption goes beyond pre-arranged trading of votes for contributions. Here the Court is hinting at the monetary influence standard.

In National Bank of Boston v. Bellotti, 20 the Court struck down a Massachusetts law forbidding corporations and banks from spending money in referenda campaigns. ${ }^{21}$ The Court followed Buckley in reasoning that while the First Amendment interest in such independent expenditures is high, there is no threat of corruption because in referenda elections there is no candidate to corrupt. In a footnote the majority opinion distinguished the Massachusetts law from the longstanding Federal Corrupt Practices Act, which bars corporate spending in candidate elections:

The overriding concern behind the enactment of statutes such as the Federal Corrupt Practices Act was the problem of corruption of elected representatives through the creation of political debts. The importance of the governmental interest in preventing this occurrence has never been doubted.22

Here again the Court seems to go beyond the concern about quid pro quo vote-trading, this time to characterize corruption as "the creation of political debts." Four years later, in FEC v. National Right to Work Comm., 23 the Court again discussed the need to insure that corporate "war chests" not be used to create "political debts." 24

For the most part in these early cases the Court does little to explain its notion of corruption, and we are left to read between the lines. But Justice Rehnquist's majority opinion in the 1984

18. "To the extent that large contributions are given to secure a political quid pro quo from current and potential office holders, the integrity of our system of representative democracy is undermined." Id. at 26.

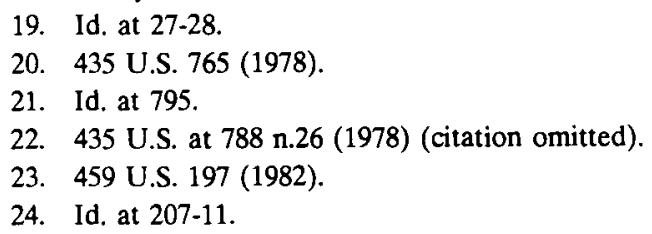


case of FEC v. National Conservative Political Action Comm.25 offers a definition:

Corruption is a subversion of the political process. Elected officials are influenced to act contrary to their obligations of office by the prospect of financial gain to themselves or infusions of money into their campaigns. The hallmark of corruption is the financial quid pro quo: dollars for political favors. 26

Here a much wider standard of corruption appears with a restatement of the familiar quid pro quo as a "hallmark." Rehnquist says that elected officials violate their public trust when they are influenced by the "prospect of financial gain to themselves or infusions of money into their campaigns." If Rehnquist had wanted to limit the corruption interest to quid pro quos, he could simply have said so. Instead he calls quid pro quo votetrading merely the "hallmark" of political corruption. In this passage, the Court again seems to be acknowledging the monetary influence standard of corruption.

Despite this acknowledgment, a clearer passage in Rehnquist's opinion in NCPAC reverts to the narrow quid pro quo standard. Relying on Buckley in distinguishing the regulation of expenditures from the regulations of contributions, Rehnquist concludes that expenditures made independently by a political action committee to support a particular candidate pose little danger of corruption. Here he emphasizes that "the absence of prearrangement and coordination undermines the value of the expenditure to the candidate, and thereby alleviates the danger that expenditures will be given as a quid pro quo for improper commitments from the candidate." 27 Overall, then, in NCPAC the Court seems to be moving towards the more narrow quid pro quo standard.

\section{Distortion}

That movement is reversed in the 1986 case FEC $v$. Massachusetts Citizens for Life, Inc.28 Justice Brennan, writing for the majority, held that a state law restricting independent expenditures for candidate elections was overbroad as applied to the appellee, a non-profit corporation. Brennan argued that advocacy groups such as MCFLI should be distinguished from profit-seek-

\footnotetext{
25. 470 U.S. 480 (1985).

26. Id. at 497 .

27. Id. at 498 .

28. 479 U.S. 238 (1986).
} 
ing corporations, who pose a real danger of distorting the political process through their accretion of wealth. Citing several earlier corporate cases, Brennan said the precedents reflected concern "about the potential for unfair deployment of wealth for political purposes." Non-profit corporations "do not pose that danger of corruption." 29 This is the only point in the opinion in which Brennan clarifies, even by implication, just what he means by corruption. Brennan's main argument is that corporate political spending poses a threat to the "political marketplace" because the "resources in the treasury of a business corporation ... are not an indication of popular support for the corporation's political ideas." 30 Here Brennan embraces the distortion standard.

Austin v. Michigan Chamber of Commerce, ${ }^{31}$ decided in 1990 , amplifies this theme and links it more clearly to the concept of corruption. The case concerned an independent expenditure made by the Chamber of Commerce to promote a candidate for the U.S. House of Representatives. In Buckley, the Court had concluded that such independent expenditures posed a relatively small risk of corruption since candidates were far less likely to feel a debt to independent spenders than contributors. In upholding a law barring such independent expenditures, the Court could merely have taken issue with this assessment and declared that independent expenditures also create political debts. ${ }^{32}$ Instead, Justice Marshall's opinion defines a new concept of corruption, borrowed partly from Brennan's opinion in MCFLI:

Regardless of whether [the] danger of "financial quid pro quo" corruption ... may be sufficient to justify a restriction on independent expenditures, Michigan's regulation aims at a different type of corruption in the political arena: the corrosive and distorting effects of immense aggregations of wealth that are accumulated with the help of the corporate form and that have little or no correlation to the public's support for the corporation's political ideas. 33

29. Id. at 259 .

30. Id. at 258 .

31. 494 U.S. 652 (1990).

32. This is what Justice Stevens, who wrote a concurring opinion, would do, at least for corporate contributions. See id. at 678-79 n.* (quoting First National Bank of Boston v. Bellotti, 435 U.S. 765,788, n.26 (1978)).

33. Austin, 494 U.S. at 659-60. In the latest Supreme Court campaign finance case, Colorado Republican Federal Campaign Comm. v. FEC, 116 S. Ct. 2309 (1996), Justice Breyer's plurality opinion steers clear of the distortion standard of corruption but does not clearly embrace either the quid pro quo or monetary influence standards. The case involved FECA limits on party expenditures in congressional elections. Breyer's opinion considers only the narrow question of whether independent, uncoordinated party expendi- 
Here corruption is no longer tied to the conduct of the officeholder, but instead concerns the power of the corporate spender in the political marketplace. Although some of Marshall's argument was anticipated in MCFLI, the Austin opinion represents the flowering of the distortion conception of corruption.

In a typically bombastic dissent Justice Scalia castigated the majority's "New Corruption":

Under this mode of analysis, virtually anything the Court deems politically undesirable can be turned into political corruption-by simply describing its effects as politically "corrosive," which is close enough to "corruptive" to qualify. . . . The Court's opinion ultimately rests upon that proposition whose violation constitutes the "New Corruption": Expenditures must "reflect actual public support for the political ideas espoused." This illiberal free-speech principle of "one man, one minute" was proposed and soundly rejected in Buckley. ${ }^{34}$

In Buckley, the Court had rejected equalization as a legitimate goal for campaign finance law, concluding that "the concept that government may restrict the speech of some elements of our society in order to enhance the relative voice of others is wholly foreign to the First Amendment." 35 Scalia charged that the majority had simply resurrected the equalization theory in a new guise-the New Corruption.

\section{Evaluating The Standards}

Austin's distortion standard of corruption has broad implications. As noted above, to use the term "corruption" one must have some underlying notion of an ideal state. Marshall's opinion suggests that in his ideal state expenditures are calibrated to actual public support. A deviation from this constitutes corruption and may be regulated. Because just about any private financing scheme is likely to have "distortions"-to not reflect underlying public support-Marshall's principle would justify very strong regulatory measures. ${ }^{36}$ Indeed it is difficult to square Marshall's principle with any system of private financing for political campaigns.

tures can be constitutionally limited. Following the logic of Buckley, Breyer argues that the lack of coordination between the candidate and the spender in an independent expenditure limits the danger of corruption. See Colorado Republican Federal Campaign Comm., 116 S. Ct. at 2317.

34. Austin, 494 U.S. at 684.

35. 424 U.S. at $48-49$.

36. It is important to remember that Marshall limits his principle to "the unique legal and economic characteristics of corporations." See Austin, 494 U.S. at 658-60. 
Even those who might be attracted to Marshall's ideal, or think that corporations can constitutionally be kept from throwing their monetary weight around, may shrink from describing this as a problem of corruption. "Corruption" can be used to describe any movement away from an ideal; this is the sense in which illness is a corruption of the body. But in politics "corruption" has typically had a more specific connotation: that an officeholder has been led by private inducements away from the ideal of disinterested public service. As Justice Scalia charges, the majority opinion in Austin takes advantage of this connotation by conflating the relatively uncontroversial ideal of disinterested public service with the far more problematic ideal of "undistorted" campaign finance. The rhetoric of corruption is used to champion an ideal so sweeping that, if taken literally, would condemn any imaginable private campaign finance system-and perhaps even public financing systems in which the funding is not carefully calibrated to public support.

But while Austin's standard of corruption is too broad, the quid pro quo standard is too narrow, as the Court has recognized from time to time. Indeed, if only pure vote-trading is considered corrupt, it is difficult to see how the Court could uphold any contribution limits.

The quid pro quo conception focuses on pre-arrangement as the truly corrupting aspect of vote-trading. Under this standard, it does not matter whether contributions influence public officials' stands on public policy, so long as there is no formal deal made. But deals-trades of votes for money-were outlawed long before the advent of campaign finance regulation. As Daniel Lowenstein has pointed out, many courts have held that campaign contributions can be bribes, and bribery convictions based on campaign contributions have been upheld in many jurisdictions. ${ }^{37}$ Under traditional First Amendment doctrine, regulations which impair free speech must be "narrowly tailored" to achieving a compelling state interest. If Congress could constitutionally regulate only quid pro quo corruption, it is difficult to see why it would be allowed to go beyond simple bribery laws. Why regulate so much legitimate "speech" in an effort to stop bribery when you can instead simply outlaw bribery? Contribu-

37. Such convictions have become far more common recently; see Daniel H. Lowenstein, When Is a Campaign Contribution a Bribe?, Midwest Pol. Sci. Ass'n, Chicago, Illinois, April 1996. This article updates Lowenstein's earlier article on bribery law, Political Bribery and the Intermediate Theory of Politics, 32 UCLA L. Rev. 784 (1985). For a general review of bribery and campaign finance law, see Daniel H. Lowenstein, Election Law: Cases and Materials (Carolina Academic Press, 1995). 
tion limits are only distantly related to the goal of stopping quid pro quo vote-trading, and certainly would never meet the Court's "narrowly tailored" test. 38

The truth is that the contribution limits the Court upheld in Buckley were aimed at far more than quid pro quo corruption. The Buckley Court recognized this when it concluded that "laws making criminal the giving and taking of bribes deal with only the most blatant and specific attempts of those with money to influence governmental action." 39 Instead the Court saw the problem as one of "political debts," that officials are "influenced to act contrary to their obligations of office by the prospect of ... infusions of money into their campaigns." 40 The problem recognized here is one of generalized financial influence on legislators, not pure vote-trading. 41

Indeed, it is not clear why a quid pro quo is any more corrupting than a contribution which influences a public official more indirectly. 42 In bribery law it makes sense to require that there be evidence that the official explicitly agreed to trade a vote for a contribution. Otherwise, we will never know for sure if she was influenced by the money; there will always be doubt about whether the gift was taken innocently. 43 But the object of

38. Indeed, Justice Thomas has recently made this argument. See Colorado Repub. lican Federal Campaign Comm., $116 \mathrm{~S}$. Ct. at 2328-29.

39. 424 U.S. at 27-28.

40. FEC v. National Conservative Political Action Comm., 470 U.S. at 497. See supra notes $25-27$.

41. Of course the contribution limits are partly justified on the other ground given in Buckley, the appearance of corruption. The Court has, however, not given much consideration to this second interest, perhaps because it seems so open-ended: just about everything that happens in Washington may appear corrupt to somebody. In practice the Court has often invoked the "appearance of corruption" standard, but has not given it any independent weight.

Dennis Thompson makes a strong argument in favor of the appearance standard. Because "citizens cannot easily collect the evidence they need to judge the motives of politicians in particular circumstances," representatives "must avoid acting under conditions that give rise to a reasonable belief of wrongdoing." Thompson says that when representatives fail this standard "they do not merely appear to do wrong, they do wrong." Dennis F. Thompson, Ethics in Congress: From Individual To Institutional Corruption 125-26 (The Brookings Institution, 1995).

42. Thompson makes this point as well: "There is .. no good reason to believe that connections that are proximate and explicit are any more corrupt than connections that are indirect and implicit." Thompson, Ethics in Congress at 112 (cited in note 41).

43. Even in bribery law it is not absolutely clear that a public official must agree to a quid pro quo to be convicted. In McCormick v. United States, 500 U.S. 257, 271-74 (1991), the Supreme Court reversed a bribery conviction because the jury had been instructed that no quid pro quo was necessary to make a campaign contribution illegal. The Court concluded that to allow a conviction without evidence of an explicit trade would cast a shadow over everyday politics and make all legislators vulnerable to prosecution. Id. A later decision, Evans v. United States, 504 U.S. 255 (1992), has thrown some confusion on this holding, however. Some courts have interpreted bribery laws as prohibiting gifts that 
bribery laws is not the deal itself; the deal is just evidence that influence has taken place. The reason we make bribery illegal is that we don't want officials to be affected by monetary considerations, not that we have a particular animus against deal-making. Even in bribery, then, the problem is not quid pro quo corruption, but the corruptive influence of money. Campaign finance laws can address this problem by creating a contribution system that limits the influence of money. Thus it makes no sense to say that the contribution limits are aimed only at quid pro quo corruption.

At times Court opinions seem to realize this. At other times the Justices lapse back into quid pro quo language, perhaps because they realize the open-endedness of considering general financial influence a problem. If the ideal is a system in which public officials are not influenced by campaign contributions, how broadly should campaign finance laws be allowed to sweep? One can imagine that, at the least, more extensive campaign regulation would be upheld under this standard. 44 Nonetheless, the Court in its more thoughtful moments has employed the monetary interest standard. When the prospect or the receipt of campaign money influences the behavior of public officials, they are corrupted, whether or not a deal has been made. Although the goal of stopping this kind of corruption must be weighed against First Amendment interests, the Court has upheld contribution limits on this basis.

\section{DOES MONEY CORRUPT?}

I have argued that the Court is on firmest ground when it adopts the "monetary influence" standard of corruption. But what is it about monetary influence-or for that matter quid pro

do not involve explicit quid pro quos. In United States v. Coyne, 4 F.3d 100 (2d Cir. 1993), a county executive in New York State was convicted under the federal Hobbs Act for taking a $\$ 30,000$ gift from a constituent. An appeals court concluded that the jury did not need evidence of an explicit quid pro quo as long as it concluded that Coyne "accepted the $\$ 30,000$ knowing that it was payment related to his using his influence as County Executive on (the constituent's) behalf as specific opportunities arose." Id. at 111 . This example involved a gift rather than a campaign contribution, and Lowenstein argues that courts may correctly choose to invoke the more explicit quid pro quo standard in campaign finance cases. But in this, as in many other aspects of bribery statutes, the law is unclear. Lowenstein concludes that the lack of clarity and stability in bribery law reflects confusion over what exactly should be considered corrupt-the same problem the Supreme Court has had in the campaign finance cases. See Lowenstein, When Is a Campaign Contribution a Bribe? (cited in note 37 ).

44. For instance, the Court might, if it more straightforwardly embraced the "monetary influence" conception of corruption, uphold a law regulating independent expenditures in candidate elections. 
quo trading - that is so corrupting? On what basis can we say that public officials who are influenced by contributions are corrupt?45 Because the Court does not develop its own account of what makes an action corrupt, we must go beyond the campaign finance cases to answer these questions.

Daniel Lowenstein argues that the "payment of money to bias the judgment or sway the loyalty of persons holding positions of public trust is a practice whose condemnation is deeply rooted in our most ancient heritage." 46 Lowenstein believes that there is a strong cultural norm in our society that public officials not be influenced by money, in the form of either gifts or campaign contributions. As evidence, Lowenstein cites both the

45. A related question is whether campaign contributions actually do infiuence representatives. The short answer, drawn from a growing body of evidence, is that contributions do influence representatives, but less than many suppose. Political scientists have produced a wealth of studies on this question but are only beginning to answer it. Most of the studies have attempted to measure the influence of PAC contributions on votes on the floor. While the results are mixed, most of the studies find only small effects. Contributions seem to go to representatives already inclined-by ideology or constituency-to support the contributor. But floor voting is only the tip of the iceberg of legislative activity.

There is little investigation of how contributions influence behavior in committee, where most legislating (and deliberating) gets done, though one study found significant effects on legislators' level of activity on behalf of contributors. See Richard L. Hall and Frank W. Wayman, Buying Time: Moneyed Interests and the Mobilization of Bias in Congressional Committees, 84 Am. Pol. Sci. Rev. 797 (1990). Similarly there is a paucity of research on how contributions influence representatives' willingness to meet with constituents or intervene for them in administrative disputes (like the Keating affair). On the access issue, see Laura I. Langbein, Money and Access: Some Empirical Evidence, $48 \mathrm{~J}$. of Politics 1052 (1986). On floor voting, see Henry W. Chappell, Jr., Campaign Contributions and Voting on the Cargo Preference Bill: A Comparison of Simultaneous Models, 36 Public Choice 301 (1981); Henry W. Chappell, Jr., Campaign Contributions and Congressional Voting: A Simultaneous Probit-Tobit Model, 64 Rev. of Economics and Statistics 77 83 (1982); Garey Durden and Jonathan Silberman, Determining Legislative Preferences on the Minimum Wage: An Economic Approach, 84 J. of Pol. Economy 317 (1976); Diana Evans, PAC Contributions and Roll-Call Voting: Conditional Power in Allan J. Cigler and Burdett A. Loomis, eds., Interest Group Politics (Congressional Q., 2d ed. 1986); John P. Frendreis and Richard W. Waterman, PAC Contributions and Legislative Behavior: Senate Voting on Trucking Deregulation, 66 Soc. Sci. Q. 401 (1986); Janet M. Grenzke, PACs and the Congressional Supermarket: The Currency is Complex, 33 Am. J. of Pol. Sci. 1 (1989); James B. Kau and Paul H. Rubin, Congressmen, Constituents and Contributors: Determinants of Roll Call Voting in the House of Representatives (Martinus Nijhoff, 1982); Jean Reith Schroedel, Campaign Contributions and Legislative Outcomes 39 Western Pol. Q. 371 (1986); W.P. Welch, Campaign Contributions and Legislative Voting: Milk Money and Dairy Price Supports, 35 Western Pol. Q. 478 (1982); Allen Wilhite and John Theilmann, Labor PAC Contributions and Labor Legislation: A Simultaneous Logit Approach, 53 Public Choice 267 (1987); John R. Wright, PACs, Contributions, and Roll Calls: An Organizational Perspective 79 Am. Pol. Sci. Rev. 400 (1985); John R. Wright, Contributions, Lobbying and Committee Voting in the U.S. House of Representatives, 84 Am. Pol. Sci. Rev. 417 (1990).

46. Daniel Hays Lowenstein, On Campaign Finance Reform: The Root of All Evil is Deeply Rooted, 18 Hofstra L. Rev. 301, 302 (1989). 
writings of various scholars on the subject, and the law of bribery, which in many jurisdictions makes quid pro quo campaign contributions illegal.47 Thus Lowenstein appeals to the public opinion and legal norms approaches in defining financial influence as corruption. As noted earlier, these are problematic appeals. Lowenstein has no polling data to show that the vast majority of Americans agree with his norm, but even if he did we might still contend that Americans are simply misguided in believing that financial influence is corrupting. Martin Shapiro argues that Lowenstein, by operating as a "cultural anthropologist," might be able to discover a societal norm, but that such a norm cannot be the basis of constitutional law: "There is a cultural norm of racism in our society. Does the existence of such a norm give constitutional legitimacy to racist statutes?"48 Shapiro maintains that Lowenstein cannot define what is corrupt merely by reference to social norms or legal principles. Even the fact that bribery statutes often cover campaign contributions traded for political favors is not determinative. Only a theoretical argument can answer the question. Everything else is questionbegging. 49

Thus any serious thinking about corruption must move us back to first principles, to fundamental beliefs about government. The debate over the place of corruption in campaign finance ultimately turns on the theoretical foundations of representative democracy.

In several recent articles Dennis Thompson has grounded his approach to legislative ethics in a theory of representation which stresses deliberation. The debate between Thompson and Bruce Cain, another expert on campaign finance, illustrates the deep roots of the controversy over corruption.

\section{Representation and Deliberation}

Thompson advances a seemingly simple notion: In a functioning democracy, representatives must deliberate about the public good. Private interests have a legitimate place in a democracy as long as they subject themselves to "the rigors of the democratic process." To get their way, private interests must convincingly articulate public purposes. 50

47. See generally id.

48. Martin Shapiro, Corruption, Freedom and Equality in Campaign Financing, 18 Hofstra L. Rev. 385, 387 (1989).

49. Id. at $387-94$.

50. Thompson, Ethics in Congress at 28 (cited in note 41 ). The only alternative is logrolling, but recent research suggests that logrolling is both more difficult and more rare 
Private interests which attempt to bypass this deliberative process are "agents of corruption." 51 They tempt representatives to ignore public purposes and to pay attention to influences "that are clearly irrelevant to any process of deliberation." 52

What influences are clearly irrelevant? Thompson gives as his primary example personal gain. Personal gain tends to take time and attention away from what should be the job of the legislator and can overwhelm the "unsteady inclination to pursue the public good."53 Thus bribes, for example, corrupt the deliberative process.

Campaign contributions, Thompson says, are different from bribes because they are a necessary part of the political process. Moreover, Thompson says we should admire those who, within limits, pursue political gain, including campaign contributions. ${ }^{54}$ But campaign contributions corrupt deliberative democracy when they influence representatives to change their stands or to refocus their energies.55 Thus Thompson accepts what I have called the "monetary influence" standard of corruption. For him, campaign contributions that seek to influence elections are vital to the democratic process, but those that seek to influence the representatives' decisions corrupt the process. Thompson shows how a deliberative theory of representation leads to a "monetary influence" standard of corruption.

In a recent article, however, Bruce Cain rejects both deliberative theory and the monetary interest standard. Cain argues that deliberative theory is "excessively restrictive and very naive," and that it is out of step with the philosophical foundations of American government. 56 Further, Cain suggests that Thomp-

than is commonly supposed. See Keith Krehbiel, Information and Legislative Organization (U. of Michigan Press, 1991). Of 29 case studies of legislation considered in Congress between 1945 and 1970, Joseph Bessette found only four examples of logrolling. And even in those cases logrolling turned out to be only a small part of the story, with deliberation on the merits also playing an important role. Bessette even argues that the case often held up as the paradigmatic instance of logrolling, the creation of the food stamp program, was more a matter of deliberation. Joseph M. Bessette, The Mild Voice of Reason: Deliberative Democracy and American National Government 67-99 (U. of Chicago Press, 1994).

51. Thompson, Ethics in Congress at 28 (cited in note 41).

52. Id. at 20. Thompson calls this the independence principle. In his earlier writings Thompson calls it the principle of autonomy; see Political Ethics and Public Office 111-16 (Harvard U. Press, 1987). The argument is also outlined in Dennis F. Thompson, Mediated Corruption: The Case of the Keating Five, 87 Am. Pol. Sci. Rev. 369 (1993).

53. Thompson, Ethics in Congress at 21 (cited in note 41).

54. Id. at 66.

55. Id. at 117 .

56. Bruce E. Cain, Moralism and Realism in Campaign Finance Reform, 1995 U. of Chi. Legal F. 111, 120. 
son's approach relies on Edmund Burke's trustee notion of representation, which, Cain claims, is not widely accepted.

Instead Cain offers his own "procedural fairness" vision of democracy, drawn from the pluralist tradition in political science. He groups under this label theorists such as Joseph Schumpeter, Anthony Downs, Robert Dahl, and James Madison (or at least, Dahl's rendition of Madison). What these otherwise disparate theorists share, according to Cain, is an approach to politics that is nondeliberative. Each treats democracy as a matter of preference aggregation, and each expects representatives to act as delegates in order to be elected.57 For proceduralists, Cain seems to conclude, the notion of corruption in campaign finance is simply meaningless. If, after all, politics is simply a matter of counting preferences, campaign contributions can be seen as a kind of vote, a way to signal the direction (and intensity) of one's desires. Money is then just another currency in the counting process, one which advantages some groups and disadvantages others. The only real issue in campaign finance, according to Cain, is how to

Cain also claims that the deliberative theory "rests on the rationalist's faith that right reasons can be found for actions, and that political discourse will lead to the discovery of commonly acknowledged truth." Id. at 120 . The first charge is true only in the modest sense that deliberative theory demands that representatives give reasons for their actions and that debate focus on the adequacy of those reasons (see the discussion of Cass Sunstein's "republic of reasons," supra note 56). As to the second charge, that deliberative theorists naively believe that debate will lead to consensus, nothing in deliberative theory necessitates this belief. If people are completely immune to persuasion, then of course deliberation is futile. But as long as debate is capable of moving people, then the fact of pluralism is quite compatible with deliberative theory. Hanna Pitkin eloquently expresses the deliberative view of democracy:

Political life is not merely the making of arbitrary choices, nor merely the resultant of bargaining between separate, private wants. It is always a combination of bargaining and compromise where there are irresolute and conflicting commitments, and common deliberation about public policy, to which facts and rational arguments are relevant. 1967).

Hanna Fenichel Pitkin, The Concept of Representation 212 (U. Califomia Press,

Some versions of republican theory do seem incompatible with pluralism. But as Frank Michelman has argued, republican theory at its best depends on the diversity of views "that citizens bring to the debate of the commonwealth." Michelman seeks to resolve the tension between republicanism and pluralism in his article Law's Republic, 97 Yale L.J. 1493, 1504 (1988).

57. Cain, 1995 U. of Chi. Legal F. at 122 (cited in note 56). Strictly speaking, the proceduralist representative is not really a delegate but a "rational actor." She is not committed to the norm of following the views of her constituency but simply to saving her own skin-or, as the economists like to say, maximizing her utility-whatever that involves. Normally one of the best ways to get reelected is to follow the opinion of one's constituency, so there is often a happy marriage between the delegate role and rationality, but a divorce is always possible. In a system with uncontrolled campaign contributions, for example, it may be rational for a representative to dismiss the views of a majority of her district when they conflict with the desires of a generous contributor. 
count fairly, and opinions about this will naturally differ depending on which groups one favors. 58

The conflict between Thompson and Cain is so fundamental that it is difficult to arbitrate. Perhaps the best place to start is with Cain's contention that deliberative theory is a "nontraditional conception of American democracy." 59 This is a surprising claim, for as Thompson argues, deliberation was at the center of the Framers' conception of representative government.60 The Federalist Papers, for example, justify many aspects of the Constitution-separation of powers, bicameralism, methods of election, size of legislative bodies-in terms of their effect on the deliberative process. The aim was to replace the excess of passion and "local spirit" that had overtaken state legislators with a concern for "the permanent and aggregate interests of the community," or as the Federalist Papers variously puts it, "the good of the whole," "the public weal," "great and national objects," "the great and aggregate interests," the "common interest," the "common good of the society," and the "comprehensive interests of [the] country."61 Indeed, Madison's famous defense of an extended republic in Federalist 10 was built on deliberative theory. He argued that such a republic was more likely than other systems of government

to refine and enlarge the public views by passing them through the medium of a chosen body of citizens, whose wisdom may best discern the true interest of their country and whose patriotism and love of justice will be least likely to sacrifice it to temporary or partial considerations. 62

Madison was, of course, a subtle thinker who understood the complex interplay of interests and deliberation, so one is likely to oversimplify his views by selective quotation. Yet the delibera-

58. Cain argues that "By littering the intellectual landscape with irrelevant issues, moralist/idealists obstruct the path to a full, open discussion of the public's views about the proper distribution of power and influence." Cain, 1995 U. of Chi. Legal F. at 112 (cited in note 56 ).

59. Id. at 120 .

60. Thompson, Ethics in Congress at 19 (cited in note 41).

61. This point is made by Joseph Bessette in Bessette, Mild Voice of Reason at 27 (cited in note 50) (quoting the Federalist Papers).

62. Federalist 10 (Madison) in Willmoore Kendall and George W. Carey, eds., The Federalist Papers, 77, 82 (Arlington House, 1966). Of course Madison was not so naive as to believe that representatives would always deliberate in the public interest, but he thought this ideal would be more closely approached in an extended republic, where factions would have a difficult time gaining control over the government. Daniel Lowenstein, in a review of Cain's paper, also makes the point that Madison was no "proceduralist." Daniel Hays Lowenstein, Campaign Contributions and Corruption: Comments on Strauss and Cain, 1995 U. Chi. Legal F. 163, 177. 
tive aspects of his thought cannot be denied. Over the past three decades, scholars in law, history and political science have demonstrated the profound influence of republican theory, with its emphasis on deliberation about the public good, on the thought of the Framers, particularly Madison. The historian Gordon Wood concludes that Madison and the Federalists were far from "modern-day pluralists":

They still clung to the republican ideal of an autonomous public authority that was different from the many private interests of the society.... Nor did they see public policy or the common interest of the national government emerging naturally from the give-and-take of these clashing private interests. ... Far, then, from the new national government being a mere integrator and harmonizer of the different special interests in the society, it would become a "disinterested and dispassionate umpire in disputes between different passions and interest in the State."63

\section{The Framers, in sum, embraced deliberative theory.}

The elitism of the Framers, who envisioned rule by a virtuous gentry, soon fell out of favor. ${ }^{64}$ But their concern for deliberation has lived on. A long list of studies highlights the continuing importance of deliberation in American democratic theory and practice. As Philip Selznick writes in a recent review, "Deliberative democracy is moving to the forefront of political theory."65

63. Gordon S. Wood, The Radicalism of the American Revolution 253 (Alfred A. Knopf, 1992) (quoting from a letter by Madison to Edmund Randolph, April 8, 1787, in the Papers of Madison, IX, 370, 384).

Other historians who trace the influence of republicanism on the Framers include J.G.A. Pocock, The Machiavellian Moment: Florentine Political Thought and the Atlantic Republican Tradition 506-52 (Princeton U. Press, 1975); Bemard Bailyn, The Ideological Origins of the American Revolution 22-54 (Belknap Press, 1967).

Foremost among legal scholars who have embraced republicanism are Cass Sunstein and Frank Michelman. See Cass R. Sunstein, The Partial Constitution (Harvard U. Press, 1993); and Frank Michelman, Law's Republic, 97 Yale L.J. 1493 (1988).

For a particularly forceful analysis of Madison's thinking by a political scientist, see James Q. Wilson, Interests and Deliberation in the American Republic, or, Why James Madison Would Never Have Received the James Madison Award, 23 Pol. Sci. and Politics 4, 561 (1990).

64. Wood documents this process in The Radicalism of the American Revolution at 255-305 (cited in note 63).

65. Philip Selznick, Defining Democracy Up, 119 The Public Interest 106 (1995). There is much literature on deliberative democracy in political theory. For some examples see James S. Fishkin, Democracy and Deliberation: New Directions for Democratic Reform (Yale U. Press, 1991); Joshua Cohen, Deliberation and Democratic Legitimacy, in Alan Hamlin and Philip Pettit, eds., The Good Polity: Normative Analysis of the State 17 (Basil Blackwell, 1989); John W. Kingdon, Politicians, Self-Interest, and Ideas in George E. Marcus and Russell L. Hanson, eds., Reconsidering the Democratic Public 73 (Penn- 
But attention to deliberation is hardly limited to theorists. Political scientists have confirmed the central role of deliberation in American government in their study of legislatures, courts, bureaucracies and the presidency. In his recent book on deliberative theory and practice Joseph Bessette cites thirty-three such studies.66

A few examples should suffice. Cass Sunstein argues, based on a review of the fundamentals of constitutional jurisprudence, that we live in a "republic of reasons." Courts, he says, will strike down laws based only on "naked preferences," the mere assertion of private power. To act constitutionally, legislators must provide a public-regarding rationale for their policies. It is through the process of deliberation that these rationales are articulated and judged.67 Martha Derthick and Paul Quirk trace the influence of ideas and deliberation on regulatory reform of the telecommunications, trucking and airline industries in The Politics of Deregulation.68 Richard F. Fenno finds that making "good public policy" through a careful study of issues is the dominant goal of representatives who seek a position on the Education and Labor and Foreign Affairs committees. ${ }^{69}$ As Joseph Bessette has suggested, when political scientists actually examine the process of policymaking they find plenty of deliberation going on. 70

Deliberative theory is untraditional only among some pluralist political scientists, who, beginning with Robert Dahl, have downplayed the republican and deliberative aspects of American government. The tradition from which Cain works starts not with Jefferson, Hamilton, or Madison, but rather with Arthur Bentley, David Truman, and Dahl.71 The vision of American de-

sylvania State U. Press, 1993); Amy Gutmann, The Disharmony of Democracy in John W. Chapman and Ian Shapiro, eds., Democratic Community: Nomos XXXV, 126-60 (New York U. Press, 1993); David Miller, Deliberative Democracy and Social Choice, 60 Pol. Stud. 54-67 (1992).

66. Bessette, Mild Voice of Reason notes at 251-52 (cited in note 50).

67. See Sunstein, Partial Constitution at 17-39 (cited in note 63).

68. Martha Derthick and Paul J. Quirk, The Politics of Deregulation 147-206 (The Brookings Institution, 1985).

69. Richard F. Fenno, Congressmen in Committees (Little, Brown and Co., 1973). Fenno's classic work on representation in practice is Home Style: House Members in Their Districts (HarperCollins, 1978). For an updating of this book see Jonathan Bernstein, Adrienne Bird Jamieson and Christine Trost, eds., Campaigning for Congress: Politicians at Home and in Washington (Institute of Governmental Studies Press, 1995).

70. See Bessette, Mild Voice of Reason at 67-99 (cited in note 50).

71. The most influential books in this tradition are Robert A. Dahl, A Preface To Democratic Theory (U. of Chicago Press, 1956); David B. Truman, The Governmental Process: Political Interests and Public Opinion, (Alfred A. Knopf, 2d ed. 1971); Arthur F. 
mocracy as preference aggregation 72 is widespread among political scientists and public choice theorists, but outside of these narrow realms it is hard to say how well it resonates. Whatever popular opinion would hold, though, Cain clearly underestimates the centrality of deliberative theory in American political thought and practice.

Cain's argument that Thompson relies on a trustee theory of representation, however, points to a more troubling issue. 73 In

Bentley, The Process of Government: A Study of Social Pressures (U. of Chicago Press, 1908).

72. Cass Sunstein claims that what unifies pluralists is the notion that "laws should be understood not as a product of deliberation, but on the contrary as a kind of commodity, subject to the usual forces of supply and demand." Sunstein, Partial Constitution at 2425 (cited in note 63). Similarly, Frank Michelman defines pluralism as "the deep mistrust of people's capacities to communicate persuasively to one another their diverse normative experiences .... . Pluralism, that is, doubts or denies our ability to communicate such material in ways that move each other's views on disputed normative issues towards felt (not merely strategic) agreement without deception, coercion, or other manipulation." Michelman, 97 Yale L.J. at 1493, 1507 (cited in note 63).

Whether this is characteristic of all pluralist thought is questionable. Nelson Polsby, who has done much to popularize the term "pluralism," maintains that pluralism is often caricatured by critics who argue against its most extravagant formulations. See Nelson W. Polsby, Community Power and Political Theory: A Further Look at Problems of Evidence and Inference (Yale U. Press, 2d ed. 1980). Polsby contends that on the issue of deliberation, pluralism is silent. (Polsby himself values deliberation, as is seen in his Consequences of Party Reform (Oxford U. Press, 1983)).

On this point, as on several others, there appears to be a plurality of pluralisms. Sunstein and Michelman seem to be particularly concemed with public choice approaches to politics, which can be seen as an outgrowth of pluralism but hardly encompass the sum of pluralist thought. In any case, Cain's approach-and the approach of the theorists he relies on, including Dahl-is to see politics as exclusively a matter of preference aggregation.

73. Cain offers no evidence for his contention that the delegate model of representation is more widely accepted than the trustee model. I could locate only a few instances of polling on this question. In 1938, when respondents were asked, "Do you believe that a Congressman should ... vote on any question as the majority of his constituents desire, or vote according to his own judgment?" Thirty-seven percent chose the delegate side, $54 \%$ the trustee side. (Roper Center Archives, accession number 0175920 , survey sponsored by Fortune, August 1938.) A more recent survey asked: "When your Representative in Congress votes on an issue, which should be more important-the way voters in your district feel about that issue, or the Representative's own principles and judgment about what is best for the country?" Sixty-eight percent chose the delegate side, $24 \%$ the trustee side. (Roper Center Archives, accession number 0192631, survey sponsored by Time/CNN, February 10,1993.) It is unclear whether this represents a time trend or a difference in question wording.

The vast majority of Americans probably haven't devoted much time to thinking about the delegate/trustee issue. Those who have often reject the formulation of a strict dichotomy between the two modes. When members of Congress were asked a delegate/ trustee question, some rejected it as simplistic. "Who dreamed up these stupid questions?" asked one respondent. Thompson, Political Ethics and Public Office at 99 (cited in note 52). Moreover, John Kingdon finds that the delegate/trustee dichotomy fails to capture the complex ways in which members of Congress think about and perform their jobs. John W. Kingdon, Congressmen's Voting Decisions (U. Michigan Press, 3d ed. 1989). 
fact Thompson attempts to distinguish his approach from the trustee notion. He points out that the views of the constituency and the views of the representative about what is in the public interest are likely on many issues to coincide. Where they do conflict, however, Thompson says that representatives may voice their constituents' views in order to give them a hearing in the deliberative process. As long as the process itself is deliberative, as long as it focuses on the merits of the issue, it does not matter whether the individual representative is delegate or trustee. 74 And this suggests an important difference between trustee/delegate theories of representation and deliberative theory: Where the trustee/delegate dichotomy focuses on the level of the individual representative, the deliberative theory leads us to look at what is happening to the institution as a whole.

Yet this refinement creates another difficulty, one that Thompson does not address. If in a deliberative democracy representatives can in some circumstances act as delegates for their constituents, why can they not also act as delegates for their contributors?75 I think the answer is that Thompson allows for only

Hanna Pitkin concludes that the dichotomy, which she prefers to call the "mandateindependence controversy," "poses a logically insoluble puzzle, asking us to choose between two elements that are both involved in the concept of representation." Pitkin, Concept of Representation at 165 (cited in note 56). As Pitkin, Thompson and others have suggested, we might be better off in discussions of representation if we dropped the notion of a dichotomy between trustees and delegates entirely.

74. Thompson is somewhat elusive on this point:

$[\mathrm{T}]$ he ideal legislator in a representative system does not pursue the public interest exclusively (whatever it may be). Such a legislator also has an ethical obligation to constituents that must be weighed against the obligation to a broader public. To find the balance between these obligations, even to decide whether they conflict, the legislator must consider the particular political circumstances at the time .... Ethical obligations of these kinds are contingent on what is going on in the legislative process as a whole and may differ for different members and vary over time for all members.

Ethics in Congress at 70-71 (cited in note 41). Elsewhere Thompson says that the deliberative principle "is consistent with conceptions of representation ranging from delegate to trustee." The principle requires only that representatives defend their views on public policy "in a public forum - and at the risk of political defeat." Id. at 114. Similarly:

[R]eelection or party loyalty could also count as principled reasons, when they

are consistent with ... le legislative deliberation.

Thompson, Political Ethics and Public Office at 113-14. Thompson does not specify how far this goes. At some point, presumably, the forces of constituency pressure, reelection anxiety, or party loyalty overwhelm the process of deliberation.

As these passages indicate, Thompson, like many other political theorists, is quite critical of the delegate/trustee dichotomy. See for example Thompson, Representatives in the Welfare State in Amy Gutmann, ed., Democracy and the Welfare State 131, 132-36 (Princeton U. Press, 1988).

75. This is the crux of David Strauss's argument against the deliberative approach to the concept of corruption. See David A. Strauss, What is the Goal of Campaign Finance Reform? 1995 U. of Chi. Legal F. 141. 
a narrow exception to the basic rule that representatives must deliberate. In giving voice to the views of their constituents, representatives can on some occasions move deliberation forward. But if a significant number of representatives are acting solely as delegates, ignoring not only the arguments of others but even their own views, deliberative democracy is imperiled.76 This corruption of the deliberative process is much more likely when representatives fall under the sway of their contributors. Contributor-influenced representatives are unlikely to be candid about the motivation for their actions; the last thing they want is an open examination of the quality of their reasons and their process of deliberation. Thus where contributor-influenced representatives predominate, legislative deliberation becomes a sham. By contrast, constituent-influenced legislators can acknowledge the pressures on them and, where their own views conflict with those of the constituents, can even deliberate publicly about how the two can be reconciled.77 Constituent influence can itself become a matter for deliberation in a way that contributor influence never can. Hence contributor influence is much more likely than constituent influence to have a pernicious effect on deliberative democracy.

Deliberative theory, then, provides a grounding for the monetary influence standard of corruption. If politics is nothing more than a market, and politicians nothing more than retailers, than there is no need for deliberation, and no necessary problem with "bribery" through the campaign finance process. That is the vision behind Cain's procedural theory. But if representation involves deliberation about the public good, then contributions that influence representatives are a corruption of the democratic process.

Deliberative theory is well-grounded in American political philosophy and practice. It is an attractive, approachable ideal. Its appeal explains why, despite criticisms like those voiced by Cain, academic, legal and popular debate about campaign finance continues to revolve around notions of corruption.

76. Hanna Pitkin goes so far as to say that when representatives act as pure delegates they are no longer doing something that can be called representation. See Pitkin, Concept of Representation at 210-211 (cited in note 56).

77. This is a point that Lowenstein makes; see Lowenstein, 1995 U. Chi. Legal F. at 191 (cited in note 62). 


\section{THE UTILITY OF "CORRUPTION"}

I have argued that the concept of corruption can be applied to one of the major problems in campaign finance, the influence that contributors have on the actions of representatives. The monetary influence standard of corruption has been invoked in several Supreme Court cases, but the Court has drifted in its treatment of corruption. At some points the Court characterizes the issue as a matter of vote trading, of quid pro quos. At other times, the Court has portrayed the problem as one of "distortion" of public opinion. Nonetheless, I believe the Court has been on firmest ground when it has recognized the issue as one of contributor influence.

Of course this recognition would not by itself determine the constitutionality of any particular regulatory scheme. Indeed it is just one of the factors involved. People may balance the goal of preventing corruption and the First Amendment interests at stake differently even though they recognize the legitimacy of both claims. Still, by focusing on the meaning of corruption I hope I have given some sense of its place in this mix.

Clearly corruption is a limited concept. It cannot encompass all the concerns we have about the campaign finance system. 78 Because so much stress has been put on corruption in campaign finance law, there will always be a temptation to use it more broadly to cover goals that are only partly related-to stretch its meaning, as I believe the Court has done in Austin. Austin's proclamation that the political system is corrupted when campaign contributions don't mirror public opinion cannot be maintained. "Corruption" will be drained of meaning if it becomes a mere synonym for "inequality." The concept of corruption has a worthy place in campaign finance law, and if the Court chooses to recognize other interests in campaign regulation it should not tarnish this one.

78. Cain complains that Thompson's approach to corruption fails to address many of the key issues in campaign finance, particularly the inequalities created in the election system by disparities in campaign contributions. Cain, $1995 \mathrm{U}$. of Chi. Legal F. at 122 (cited in note 56). But those who embrace corruption as an important concept in campaign finance law need not limit themselves to this one principle. The American campaign finance system is flawed in many respects, and no one principle can capture all of them.

Indeed if Cain had merely argued that too much attention is given to issues of corruption in the popular debate over campaign finance and not enough to other concerns I would be in full agreement. 